THE STORY

OF MYTH 



\title{
THE STORY OF MYTH
}

\section{Sarah Iles Johnston}

\author{
II Harvard University Press
}

Cambridge, Massacbusetts

London, England $\quad 2018$ 
Copyright $\odot 2018$ by the President and Fellows of Harvard College

All rights reserved

Printed in the United States of America

First printing

Cover design by Lisa Roberts

Cover art: John Singer Sargent / Museum of Fine Arts, Boston. Francis Bartlett Donation of 1912 and Picture Fund

978-o-674-98955-9 (EPUB)

978-o-674-98956-6 (MOBI)

978-0-674-98957-3 (PDF)

The Library of Congress has cataloged the printed edition as follows:

Names: Johnston, Sarah Iles, I957- author.

Title: The story of myth/Sarah Iles Johnston.

Description: Cambridge, Massachusetts : Harvard University Press, 2018. I

Includes bibliographical references and index.

Identifiers: LCCN 2018007634 I ISBN 9780674185074 (alk. paper)

Subjects: LCSH: Mythology, Greek—Comparative studies. I Discourse analysis, Narrative. I Heroes-Mythology-Greece.

Classification: LCC BL783 J64 2018 I DDC 292.I/3-dc23

$\mathrm{LC}$ record available at https://lccn.loc.gov/2018007634 
To

Alex and Damian

Wolfgang and Max

Archer and Hugo

Orion and Remy

For what good is a storyteller, without an audience? 
